\title{
SIMULTANEOUS ESTIMATION OF EPERISONE HYDROCHLORIDE AND PARACETAMOL IN PHARMACEUTICAL DOSAGE FORM BY REVERSE PHASE HPLC AND VALIDATION OF THE DEVELOPED METHOD
}

\author{
Nalini C. N.*, Pyda Abhinav, Ramalakshmi N., Kiran Bhatt K. and Sahini K. \\ Department of Pharmaceutical Analysis, C. L. Baid Metha College of Pharmacy, Jyothi Nagar, \\ Old Mahabalipuram Road, Thoraipakkam, Chennai, India \\ *E-mail: nalini_cn@yahoo.co.in
}

\begin{abstract}
Eperisone and paracetamol were estimated simultaneously and the developed method is validated.The principle depends on HPLC separation of the two drugs on the Phenomenex Column $(150 \mathrm{~mm} \times 4.6 \mathrm{~mm}, 5 \mu \mathrm{m})$ with a mobile phase containing Methanol: Ortho phosphoric acid (55: 45, v/v) and the flow rate being $1.0 \mathrm{~mL} / \mathrm{min}$. UV detection at $270 \mathrm{~nm}$ with a retention time of 2.84, $4.41 \mathrm{~min}$ for Eperisone hydrochloride and Paracetamol respectively. The calibration plots showed a good linear relationship over the concentration range of $10.07-100.65 \mu \mathrm{g} / \mathrm{mL}$ for Paracetamol, $10.08-100.83 \mu \mathrm{g} / \mathrm{mL}$ for Eperisone hydrochloride. The method was validated for all the parameters according to International Council for Harmonisation guidelines. This method was found to be Statistically repeatable and selective for the simultaneous estimation of the two drugs in pharmaceutical dosage form. It can also be applied routine quality control of raw materials of the drugs.
\end{abstract}

Keywords: Paracetamol, Eperisone hydrochloride, RP-HPLC, Validation, ICH

๑ ( RASĀYAN. All rights reserved

\section{INTRODUCTION}

A combination of Paracetamol (PAR) and Eperisone hydrochloride (EPE) is used as an analgesic, antispasmodic, antipyretic and antacid. ${ }^{1-3} \mathrm{~A}$ thorough study of the Previous literature revealed that methods have been reported for analysis of Paracetamol and Eperisone hydrochloride in pharmaceuticals, including High-performance liquid chromatography and HPLC/MS methods for quantitation in human plasma either alone or in combination with other drugs ${ }^{4}$. This paper describes the simultaneous quantitation of PAR and EPE by reverse phase -HPLC in a pharmaceutical dosage form for the first time. Validation according to International Conference on Harmonization (ICH) guidelines for the developed method was also carried out.

\section{Reagents}

\section{EXPERIMENTAL}

Paracetamol and Eperisone hydrochloride were obtained from Corpuscle research solutions, Visakhapatnam, A.P. Fixed-dose combination tablets (MYOSONE PLUS) containing 50mg of Eperisone hydrochloride and $325.5 \mathrm{mg}$ of Paracetamol were procured from EASAI PHARMACEUTICALS Pvt Ltd., Visakhapatnam, A.P. All chemicals and reagents were of analytical grade and were purchased from Merck Chemicals, Mumbai (Maharashtra, India)

\section{Instrumentation}

The HPLC system consisted of Intelligent HPLC Pump (LC-10ATvp binary pump) with sampler connected with the UV-Visible detector. The data acquisition was performed by LC Solutions version 1.23 software.

\section{Chromatographic Conditions}

The Column used was Phenomenex column $(150 \mathrm{~mm} \times 4.6 \mathrm{~mm}, 5 \mu)$ with ambient mobile phase containing Methanol: Ortho phosphoric acid (55: 45, v/v) at a flow rate of $1.0 \mathrm{~mL} / \mathrm{min}$. 


\section{Preparation of Standard Stock Solution}

About 100mg of Paracetamol and 100mg of Eperisone Hydrochloride were accurately weighed into a $1000 \mathrm{ml}$ volumetric flask. To this, $100 \mathrm{ml}$ of diluent $(50 \%$ Methanol: Water) was added. This gives $1000 \mu \mathrm{g} / \mathrm{ml}$ solution which is used as stock solution. It is sonicated and then made up to required volume with the diluent and then filtered using $0.45 \mu \mathrm{m}$ membrane filter.

\section{Preparation of Sample Stock Solution}

Twenty tablets of MYOSONE PLUS were taken (each tablet containing 50mg of Eperisone hydrochloride and 325mg of Paracetamol) into a mortar and finely powdered with a pestle. An equivalent weight of powder containing 100mg of Eperisone hydrochloride and $100 \mathrm{mg}$ of Paracetamol was accurately weighed and transferred to a $100 \mathrm{ml}$ volumetric flask and diluted with $50 \%$ Methanol : water and shaken mechanically for ten minutes and then centrifuged. The clear supernatant liquid was taken and sonicated in an ultrasonic bath for 5 minutes. The filtration was affected by the $0.45 \mu \mathrm{m}$ membrane filter. The final volume was made up of 50\% Methanol: water. Working standard solutions were prepared with a diluent of the mobile phase.

\section{Preparation of Mobile Phase}

$0.5 \mathrm{~mL}$ of Ortho Phosphoric acid was added to $500 \mathrm{ml}$ of water. It was mixed well, degassed and filtered through a $0.45 \mu \mathrm{m}$ membrane filter. $500 \mathrm{ml}$ of Methanol was added and the above prepared $0.1 \%$ ortho phosphoric acid was added to it and finally the filtration was effected by a $0.45 \mu \mathrm{m}$ membrane filter, then degassing was performed.

\section{RESULTS AND DISCUSSION}

The proposed method for the simultaneous determination of Paracetamol and Eperisone hydrochloride was found to be a suitable method. Various chromatographic conditions like the mobile phase composition, $\mathrm{pH}$, and buffers used in the mobile phase were changed and the suitable one was selected ${ }^{5,-10}$. The various ratios for the mobile phase composition were checked. A mixture of Methanol: $0.1 \%$ ortho phosphoric acid buffer in the ratio of $(55: 45 \mathrm{v} / \mathrm{v})$ was found to be the suitable mobile phase composition. Assay chromatogram is illustrated in Fig.1. The RT (retention times) of PAR and EPE were 2.84 and 4.41 min respectively. The concentrations $10.07-100.65 \mu \mathrm{g} / \mathrm{ml}$ were taken for checking the linearity of the method for PAR and $10.08-100.83 \mu \mathrm{g} / \mathrm{ml}$ for EPE. Linearity solutions were injected in triplicate and the calibration graphs were plotted as peak area of the analyte against the concentration of the drug in $\mu \mathrm{g} / \mathrm{ml} .{ }^{11,12}$ Figure-2 shows that , the calibration graphs were linear for both the analytes in the mentioned concentrations and the correlation coefficients for the regression line were 0.994 and 0.990 for PAR and EPE respectively.

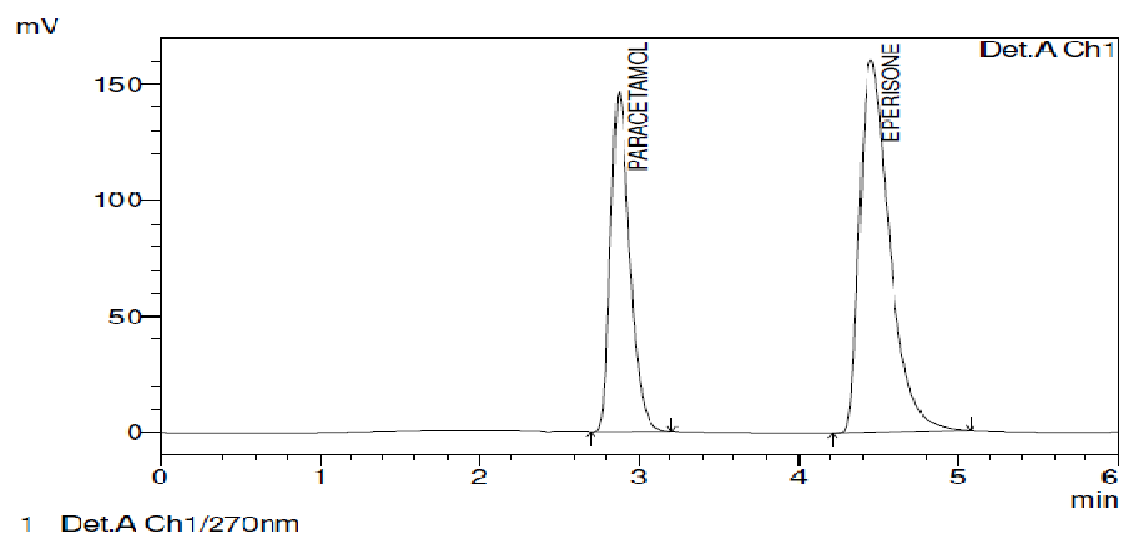

Fig.-1: Chromatogram of assay sample

The recovery experiments were performed to study te accuracy of the method ${ }^{13},{ }^{14}$ Determination at three levels, viz. 50\%, 100\%, 150\% of the selected concentrations were carried out for recovery studies. The 
recovery level is studied in three samples. The recovery values and was found to be 92.77 to 98.09 for PAR and 97.03 to 98.68 for EPE (Table-1a and 1b). Intra and Inter-day studies were performed by taking six replicates of three concentrations for precision studies. The results are shown in (Table-2). The limit of detection (LOD) and limit of quantitation (LOQ) for PAR, EPE was 7.49, 10.81 and 15.56, 12.24 respectively. The robustness of the developed method was checked by altering the experimental conditions and RSD of the peak areas of PAR and EPE were found not greater than 2.0 illustrate the robustness of the method. (Table -4). Table-5 describes the results of acid stress, alkali stress, oxidative stress, photolytic stress for PAR and EPE.

Table-1a: Accuracy Data for Paracetamol

\begin{tabular}{c|c|c|c|c}
\hline S. No. & \multicolumn{2}{|c|}{ Peak Retention Time } & \multicolumn{2}{c}{ Peak Area } \\
\hline & PAR & EPE & PAR & EPE \\
\hline 1 & 2.67 & 4.11 & 1603908 & 2759185 \\
\hline 2 & 2.68 & 4.13 & 1492474 & 2564585 \\
\hline 3 & 2.69 & 4.14 & 1565177 & 2686468 \\
\hline 4 & 2.68 & 4.14 & 1158129 & 1973693 \\
\hline 5 & 2.68 & 4.13 & 1525862 & 2613211 \\
\hline 6 & 2.43 & 3.74 & 1609334 & 2726500 \\
\hline MEAN & 2.638 & 4.065 & 1492480.7 & 2553940.3 \\
\hline STDEV & 0.1023 & 0.1596 & 169859.27 & 293182.22 \\
\hline \%CV & 3.88 & 3.93 & 11.38 & 11.48 \\
\hline
\end{tabular}

Table-1b: Accuracy data for Eperisone

\begin{tabular}{c|c|c|c|c|c|c}
\hline S.No. & Sample ID & $\begin{array}{c}\text { Concentration in } \\
\mu \mathrm{g} / \mathrm{ml}\end{array}$ & $\begin{array}{c}\text { Amount } \\
\text { found }\end{array}$ & Mean & $\%$ recovery & RSD \\
\hline 1 & & 24.76 & & & \\
2 & LQC & 25.16 & $\begin{array}{l}24.26 \\
24.00\end{array}$ & 24.34 & 96.74 & 1.60 \\
3 & & & 48.92 & & & \\
\hline 1 & & & 48.27 & 49.09 & 98.09 & 1.88 \\
2 & MQC & 50.05 & 50.09 & & & \\
3 & & & 71.74 & & & \\
\hline 1 & & & 69.37 & 69.65 & 92.77 & 2.81 \\
2 & HQC & 75.08 & 67.85 & & & \\
\hline
\end{tabular}

Table-2: Precision of Paracetamol and Eperisone

\begin{tabular}{c|c|c|c|c|c|c}
\hline S.No. & Sample ID & $\begin{array}{c}\text { Concentration } \\
\text { in } \mu \mathrm{g} / \mathrm{ml}\end{array}$ & $\begin{array}{c}\text { Amount } \\
\text { Found }\end{array}$ & Mean & $\%$ recovery & RSD \\
\hline 1 & & & 25.37 & & & \\
2 & LQC & 25.21 & 24.87 & 24.88 & 98.68 & 2.00 \\
3 & & & 24.38 & & & \\
\hline 1 & & 50.05 & 48.87 & 48.91 & 97.03 & 2.38 \\
2 & MQC & & 47.77 & & & \\
3 & & & 72.76 & & & \\
\hline 1 & & & 72.93 & 73.64 & 97.39 & 1.88 \\
2 & HQC & 75.08 & 75.24 & & & \\
\hline
\end{tabular}


RASĀYAN J. Chem.

Vol. 10 | No. 4 |1500-1504| October - December | 2017
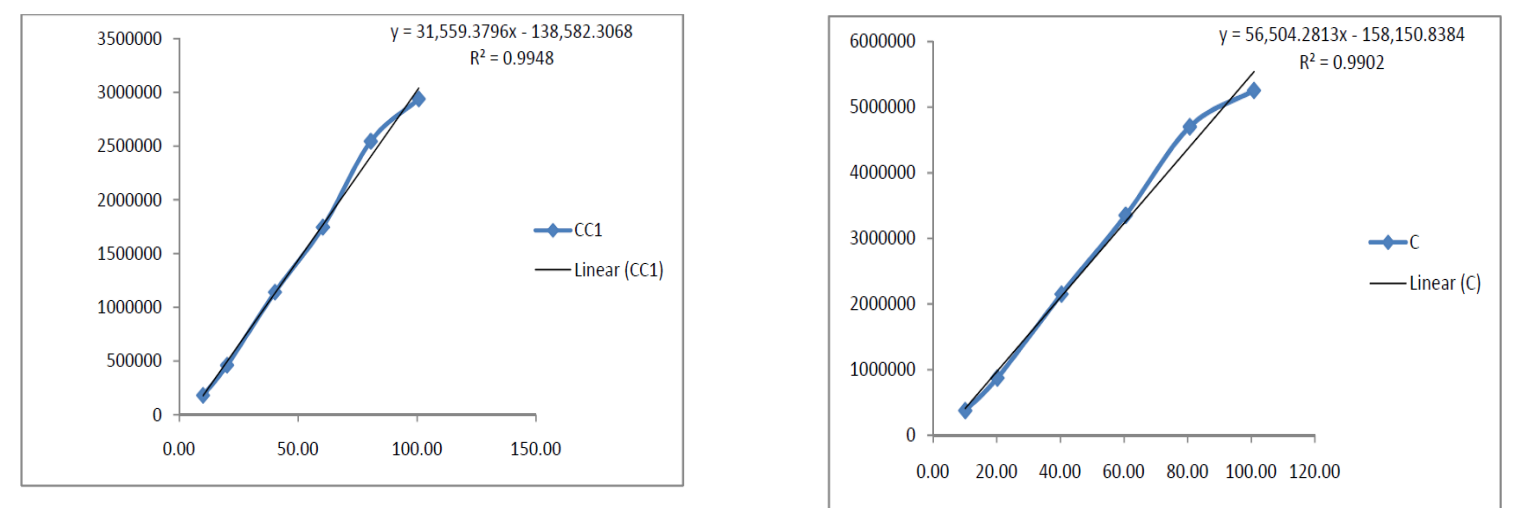

Fig.-2: Linear Calibration Curve of Paracetamol and Eperisone

Table-3a: Assay of Paracetamol

\begin{tabular}{c|c|c|c}
\hline S.No. & \multicolumn{2}{|c|}{ Drug } & \\
\hline & Retention Time & Peak Area & Tailing Factor \\
\hline 1 & 2.87 & 1189772 & 1.41 \\
\hline 2 & 2.79 & 1314468 & 1.41 \\
\hline 3 & 2.86 & 1475200 & 1.42 \\
\hline MEAN & 2.8 & 1326480.0 & 1.413 \\
\hline ST & 0.04 & 143092.63 & 0.01 \\
DEV & 1.53 & 10.79 & 0.41 \\
\hline$\% \mathrm{CV}$ & \multicolumn{2}{|c}{} \\
\hline
\end{tabular}

Table-3b: Assay of Eperisone

\begin{tabular}{c|c|c|c}
\hline S.No. & \multicolumn{2}{|c|}{ Drug } & \\
\hline & Retention Time & Peak Area & Tailing Factor \\
\hline 1 & 4.45 & 2081503 & 1.57 \\
\hline 2 & 4.34 & 2311487 & 1.57 \\
\hline 3 & 4.44 & 2548691 & 1.58 \\
\hline MEAN & 4.4 & 2313893.7 & 1.6 \\
\hline ST & 0.06 & 233603.30 & 0.01 \\
\hline DEV & 1.38 & 10.10 & 0.37 \\
\hline
\end{tabular}

Table-4: Robustness of Paracetamol and Eperisone

\begin{tabular}{c|c|c|c|c}
\hline \multicolumn{2}{l|}{} & \multicolumn{2}{c|}{ Tailing factor } & Acceptance Criteria \\
\hline \multicolumn{2}{l|}{ Proposed variations } & Paracetamol & Eperisone & \\
\cline { 1 - 4 } Variation in Flow & $0.9 \mathrm{ml}$ & 1.43 & 1.58 & \\
\cline { 2 - 4 } Rate & $1.1 \mathrm{ml}$ & 1.42 & 1.54 & \multirow{3}{*}{ In between 0.5 and 2.0} \\
\hline Variation in mobile & $50: 50$ & 1.45 & 1.73 & \\
\cline { 2 - 4 } phase composition & $60: 40$ & 1.46 & 1.57 & \\
\hline
\end{tabular}

\section{CONCLUSION}

The RP-HPLC method for analysis of Paracetamol and Eperisone was found to be satisfactory in terms of all the validation parameters prescribed by ICH guidelines. Therefore it was concluded that the 
RASĀYAN $J$. Chem.

Vol. 10 | No. 4 |1500-1504| October - December | 2017

proposed method Paracetamol and Eperisone pharmaceutical dosage forms can be used for routine analysis.

Table-5: Results of Stress Studies

\begin{tabular}{c|c|c|c|c}
\hline \multirow{2}{*}{ Sample ID } & \multicolumn{2}{|c|}{ Retention time } & \multicolumn{2}{c}{ \% Stability } \\
\cline { 2 - 5 } & PAR & EPE & PAR & EPE \\
\hline Fresh sample & 2.82 & 4.34 & - & - \\
\hline Acid stress & 2.82 & 4.37 & 108.81 & 92.14 \\
\hline Alkaline stress & Peak distorted & Peak distorted & 00.00 & 00.00 \\
\hline Oxidative stress & 2.8 & 4.40 & 98.56 & 95.75 \\
\hline Photolytic stress & 2.82 & 4.37 & 101.48 & 79.10 \\
\hline
\end{tabular}

\section{REFERENCES}

1. M .Fujioka and Kuriyama H. J. Pharmacol. Exp .Ther. 235(3), 757(1985).

2. L.Nelson, C.David, M. Michael. Lehninger Principles of Biochemistry, Edition III. New York. p. 643 (2000).

3. L. Altun, Turk J Chem, 26, 521 (2002).

4. P.U .Patel, S.K Patel, and U.J Patel, International Research Journal of Pharmacy, 3(9), 203(2012).

5. Skoog, Fundamentals of Analytical Chemistry, Edition VIII, Thomson Asiapte Ltd., p. 2, 785(2004).

6. S.M Khopkar. Basic Concepts of Analytical Chemistry, New age international publishers, p.178 (1986).

7. R. Lloyd Synder Practical HPLC Method Development. John Wiley \& Son's publishers, Edition II, p. 350(1997).

8. C.Marvin. HPLC - A Practical Users Guide. John Wiley \& Sons. Inc, II Edition, p.14 (2007).

9. B.K Sharma. Text Book on validation of analytical procedures. ICH Harmonized tripartite guidelines, p.34-62 (1999).

10. ICH, Validation of Analytical procedures Text and methodology (Q2(R1)) International Conference on Hormonization, Geneva (2005).

11. ICH HarmonizedTripartite Guidelines, Validation of Analytical Procedures Text and Methodology, Q2 (R1), Geneva (2005).

12. ICH, Text on Validation of Analytical Procedures, ICH-Q2A, International Conference on Harmonization, IFPMA, Geneva, 2(3), A-1(1995).

13. D. Murali. and C. Rambabu. RasayanJ.Chem, 9(1), 67(2016).

14. Chandrabatla Varaprasad, Md. Asif and K.Ramakrishna, Rasayan J. Chem, 8(4), 426(2015).

15. Gopal Ji Baranwal, Savita Upadhyay, Avinash C. Tripathi and Shailendra K. Saraf Rasayan J. Chem,8(3), 287(2015).

[RJC-1898/2017] 